\title{
Low Carbon Operation of Super-Large Blast Furnaces in China
}

\author{
Zheng-jian LIU, ${ }^{1,2) *}$ Jian-liang ZHANG ${ }^{1,2)}$ and Tian-jun YANG ${ }^{1,2)}$ \\ 1) School of Metallurgical and Ecological Engineering, University of Science and Technology Beijing, Beijing, 100083 China. \\ 2) State Key Laboratory of Advanced Metallurgy, University of Science and Technology Beijing, Beijing, 100083 China.
}

\author{
(Received on September 8, 2014; accepted on January 6, 2015)
}

\begin{abstract}
There are 19 super-large blast furnaces more than $4000 \mathrm{~m}^{3}$ running in China currently, and significant progresses of low carbon operation were obtained in recent years. In this paper, low carbon operation technologies of Chinese super-large blast furnaces were illustrated in the two aspects of raw materials preparation and blast furnace operation. Firstly in terms of raw materials preparation, low carbon operation technologies include producing low $\mathrm{SiO}_{2}$ content and high reducibility sinter to reduce slag volume and improve sinter metallurgical properties; optimizing coal blending structure for coking to guarantee coke quality; implementing blending yard technology to stabilize blast furnace operation; controlling harmful elements load to reduce their damage to coke; adopting screening technology to reduce dust amount; recycling small size sinter, nut coke and $\mathrm{CDO}$ dust to improve ironmaking energy efficiency. Secondly in terms of blast furnace operation, low carbon operation technologies include improving gas utilization efficiency by upper adjustment and lower adjustment, the upper adjustment including charging mode, batch weight and stock line level, lower adjustment including the control of blast volume and blast kinetic energy; implementing comprehensive blast technology of high blast temperature, dehumidified blast and high top pressure, promoting economic coal injection concept; conducting low silicon smelting, but should pay attention to its impact on campaign life of blast furnace; controlling thermal load to reduce heat loss, emphasizing middle-part management of blast furnace; development and application of blast furnace visualization technology to guarantee long-term smooth operation of blast furnace.
\end{abstract}

KEY WORDS: super-large blast furnace; low carbon operation; fuel rate; gas utilization efficiency; economic coal injection; blast furnace visualization technology.

\section{Introduction}

Since 2012, China has become the world's largest carbon emitter, and $\mathrm{CO}_{2}$ emissions accounted for $29 \%$ of the world. Steel industry is the focus for $\mathrm{CO}_{2}$ emission reduction, and $\mathrm{CO}_{2}$ emissions of Chinese steel industry account for about $12 \%$ of China, and $\mathrm{CO}_{2}$ emissions of ironmaking process account for nearly $90 \%$ of the whole steel industry, and the $\mathrm{CO}_{2}$ emissions of blast furnaces account for more than $70 \%$ of ironmaking process. ${ }^{1-3)}$ Therefore, the pressure for environmental protection of blast furnace ironmaking is huge and the carbon mainly comes from the fuel, which mainly consists of coke and pulverized coal in China.

The sales profit rate of Chinese key steel enterprises is only $0.62 \%$ in 2013 , and Chinese steel industry is just in a low-profit era and facing tremendous cost pressure. The cost of per ton steel mainly depends on the cost of hot metal, in which the cost of fuel is only lower than iron ore and located in the second place.

Thus, reducing fuel consumption of blast furnace is crucial to solve its dual pressures of environmental protection and production cost, and also is the key to achieving sustainable development of Chinese steel industry.,5)

Large blast furnace is an important symbol of ironmaking

\footnotetext{
* Corresponding author: E-mail: liuzhengjian@126.com DOI: http://dx.doi.org/10.2355/isijinternational.55.1146
}

development, and the super-large blast furnace (larger than $4000 \mathrm{~m}^{3}$, the same as below) has more indirect reduction zone and smaller specific surface area, which is beneficial to improve gas utilization efficiency, decrease heat loss and reduce fuel rate. The coke rate, coal rate and fuel rate of Chinese key steel enterprises' blast furnaces with different volume in 2011 are shown in Fig. 1.

Figure 1 shows the coke rate and fuel rate of super-large

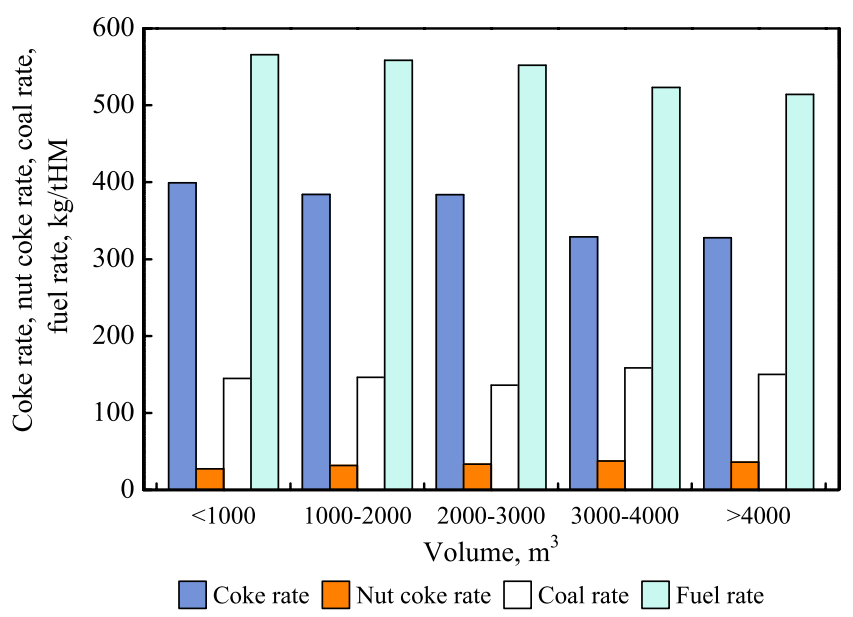

Fig. 1. Coke rate, coal rate and fuel rate of Chinese key steel enterprises' blast furnaces with different volume in 2011. (Online version in color.) 
blast furnace are respectively $71.4 \mathrm{~kg} / \mathrm{tHM}$ and $51.4 \mathrm{~kg} / \mathrm{tHM}$ lower than the one of small blast furnace (less than 1000 $\mathrm{m}^{3}$ ). In addition, comparing the $5000 \mathrm{~m}^{3}$-scale blast furnace with the $3000 \mathrm{~m}^{3}$-scale blast furnace, the cost of hot metal can be reduced by $1.2 \%$, the productivity can be increased by $30 \%$, the investment per ton iron can be reduced by $12 \%$. In 2013, Chinese crude steel output reached 779.04 million tons, and pig iron output reached 708.97 million tons. To sum up, for a country with so huge steel production capacity, the construction of super-large blast furnace is essential, and how to achieve low fuel rate of super-large blast furnace is significant to energy conservation and emissions reduction for Chinese steel industry.

\section{Development of Chinese Super-Large Blast Furnace}

The development of Chinese super-large blast furnace started late, which has gone through the initial period, lag period and flourishing period, as shown in Fig. 2.

On September 15, 1985, Baosteel No. 1 blast furnace (4 $063 \mathrm{~m}^{3}$ ) was put into operation, which is first super-large blast furnace in China, marking a boost to Chinese large blast furnace, then the development of Chinese super-large blast furnace entered the initial period. Baosteel No. 1 blast furnace was based on first generation of Nippon Steel Kimitsu plant No. 3 blast furnace and built by Nippon Steel. Despite with the guidance of Nippon steel technical staff, but due to the lack of operating experience for super-large blast furnace, Baosteel No. 1 blast furnace hearth became inactive after commission, and underwent 13 months to reach the designed target. On June 29, 1991, Baosteel No. 2 blast furnace $\left(4063 \mathrm{~m}^{3}\right)$ was put into operation, which is Chinese first self-designed, self-built and self-blow-in super-large blast furnace. The technical indexes of Baosteel No. 2 blast furnace underwent 11 months after commission to reach the designed target, that is 2 months ahead of Baosteel No. 1 blast furnace which all dependent on foreign technology.

On September 20, 1994, Baosteel No. 3 blast furnace $\left(4350 \mathrm{~m}^{3}\right)$ was put into operation, but in the next ten years there are no new-built super-large blast furnace commissioned, except for the 2nd generation of Baosteel No. 1 blast furnace (overhauled on April 2, 1996 and was put into operation on May 25, 1997), the Chinese super-large blast furnaces' number maintained at 3 and entered the lag period.

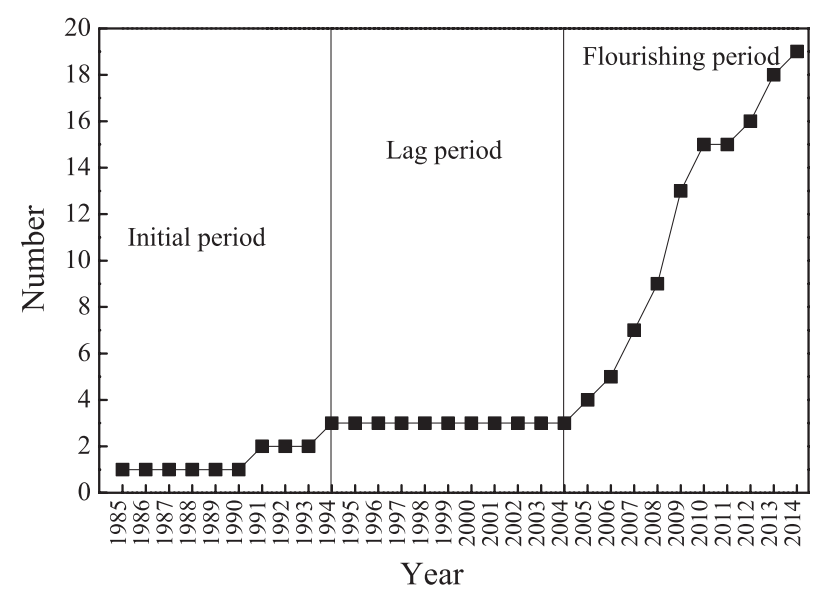

Fig. 2. Development of Chinese super-large blast furnaces.
On April 27, 2005, Baosteel No. 4 blast furnace (4 $\left.747 \mathrm{~m}^{3}\right)$ was put into operation, till May 27, 2014, Baogang No. 7 blast furnace $\left(4150 \mathrm{~m}^{3}\right)$ was put into operation, in this ten years there are 16 new-built super-large blast furnaces commissioned, and 3 overhauled super-large blast furnaces commissioned (the 2nd generation of Baosteel No. 2 blast furnace, the 3rd generation of Baosteel No. 1 blast furnace, the 2nd generation of Baosteel No. 3 blast furnace), the development of Chinese super-large blast furnace entered the flourishing period. During this period, Shougang Jingtang steel built and put $2 \times 5500 \mathrm{~m}^{3}$ super-large blast furnaces into operation, Shagang built and put $1 \times 5800 \mathrm{~m}^{3}$ super-large blast furnace into operation, a total of 3 superlarge blast furnaces greater than $5000 \mathrm{~m}^{3}$, marking the design and equipment manufacturing of Chinese super-large blast furnace have reached the world advanced level.

Taking the 1st generation of Baosteel No. 3 blast furnace as an example, the campaign life reached 6920 days, a difference of 21 days to 19 years, ranking 5th in world super-large blast furnaces; total production reached 68.29 million tons, ranking 2nd; average utilization coefficient was $2.27 \mathrm{t} /\left(\mathrm{m}^{3} \cdot \mathrm{d}\right)$, ranking $1 \mathrm{st}$; production per unit effective volume was $15700 \mathrm{t} / \mathrm{m}^{3}$, ranking 2nd; average fuel rate was $500.5 \mathrm{~kg} / \mathrm{tHM}$, and average coal rate was $180.9 \mathrm{~kg} / \mathrm{tHM}$, marking the operation and management technologies of Chinese super-large blast furnace have also reached the world advanced level.

At present, there are 19 super-large blast furnaces running in China, as shown in Table 1. ${ }^{6-12)}$ Among those 19 superlarge blast furnaces, Baosteel accounts for 5, Shougang accounts for 3, Angang accounts for 2, Tisco accounts for 2, Magang accounts for 2, Shagang accounts for 1, Wisco accounts for 1, Bengang accounts for 1 and Anyang steel accounts for 1 , the total steel capacity nearly reaches 70 million tons.

\section{Low Fuel Rate Operation Technologies of Chinese Super-Large Blast Furnaces}

In recent years, by Chinese super-large blast furnace operators' continuous efforts, the blast furnace production indexes were improved constantly, and fuel rate was declined ceaselessly, as shown in Table $2 .{ }^{13-16)}$

Reducing fuel rate is an integrated technology for low carbon operation. On the basis of ensuring raw materials quality, by guaranteeing smooth operation of blast furnace and utilizing gas thermal- and chemical- energy to reduce fuel rate. The specific technical principle is shown in Fig. 3.

\section{Raw Materials Preparation Technologies}

\subsection{Low $\mathrm{SiO}_{2}$ Content and High Reducibility Sinter Production Technology}

Using low $\mathrm{SiO}_{2}$ content sinter can increase burden Febearing grade, reduce slag volume, improve sinter metallurgical properties, especially increase soft melting temperature and narrow soft melting temperature range, which can make the position of cohesive zone downward and the thickness of cohesive zone thin, promote the indirect reduction, and improve the permeability of stock column. ${ }^{17)}$ The specific techniques include: 
ISIJ International, Vol. 55 (2015), No. 6

Table 1. Overview of Chinese super-large blast furnaces in operation.

\begin{tabular}{|c|c|c|c|c|c|}
\hline & Furnace No. & Effective volume, $\mathrm{m}^{3}$ & Commissioning date & Generation & Hearth diameter, $\mathrm{m}$ \\
\hline 1 & Baosteel No. 1 & 4966 & 2009.2 .15 & $3 \mathrm{rd}^{*}$ & 14.5 \\
\hline 2 & Baosteel No. 2 & 4706 & 2006.12 .7 & $2 \mathrm{nd}^{* *}$ & 14.5 \\
\hline 3 & Baosteel No. 3 & 4850 & 2013.11.16 & $2 \mathrm{nd}^{* * *}$ & 14.2 \\
\hline 4 & Baosteel No. 4 & 4747 & 2005.4.27 & 1st & 14.0 \\
\hline 5 & Tisco No. 5 & 4350 & 2006.10 .13 & 1st & 14.2 \\
\hline 6 & Magang No. A & 4000 & 2007.2 .8 & 1st & 13.5 \\
\hline 7 & Magang No. B & 4000 & 2007.5 .24 & 1 st & 13.5 \\
\hline 8 & Angang Bayuquan No. 1 & 4038 & 2008.9.6 & 1 st & 13.3 \\
\hline 9 & Bengang New No. 1 & 4747 & 2008.10 .9 & 1 st & 14.2 \\
\hline 10 & Angang Bayuquan No. 2 & 4038 & 2009.4.26 & 1 st & 13.3 \\
\hline 11 & Shougang Jingtang Steel No. 1 & 5500 & 2009.5.21 & 1 st & 15.5 \\
\hline 12 & Wisco No. 8 & 4096 & 2009.8.1 & 1 st & 13.6 \\
\hline 13 & Shagang $5800 \mathrm{~m}^{3}$ & 5800 & 2009.10 .20 & 1 st & 15.3 \\
\hline 14 & Shougang Qianan Steel No. 3 & 4000 & 2010.1.8 & 1 st & 13.5 \\
\hline 15 & Shougang Jingtang Steel No. 2 & 5500 & 2010.6 .26 & 1 st & 15.5 \\
\hline 16 & Baosteel Meigang No. 5 & 4070 & 2012.6 .2 & 1 st & 13.3 \\
\hline 17 & Anyang Steel No. 3 & 4836 & 2013.3.19 & 1st & 14.2 \\
\hline 18 & Tisco No. 6 & 4350 & 2013.11 .7 & 1 st & 14.2 \\
\hline 19 & Baogang No. 7 & 4150 & 2014.5.27 & 1 st & 12.9 \\
\hline
\end{tabular}

Note:

* Baosteel No. 1 blast furnace: the 1st generation (4 $\left.063 \mathrm{~m}^{3}, 1985.9 .15-1996.4 .2\right)$, the 2nd generation $\left(4063 \mathrm{~m}^{3}, 1997.5 .25-\right.$ 2008.8.30)

** Baosteel No. 2 blast furnace: the 1st generation $\left(4063 \mathrm{~m}^{3}, 1991.6 .29-2006.8 .31\right)$

*** Baosteel No. 3 blast furnace: the 1st generation (4 $\left.350 \mathrm{~m}^{3}, 1994.9 .20-2013.8 .29\right)$

Table 2. Production indexes of Chinese super-large blast furnaces in 2013.

\begin{tabular}{|c|c|c|c|c|c|c|c|c|}
\hline & Furnace No. & $\begin{array}{l}\text { Productivity, } \\
\mathrm{t} /\left(\mathrm{m}^{3} \cdot \mathrm{d}\right)\end{array}$ & $\begin{array}{c}\text { Blast } \\
\text { temperature, }{ }^{\circ} \mathrm{C}\end{array}$ & $\begin{array}{c}\text { Fuel rate, } \\
\mathrm{kg} / \mathrm{tHM}\end{array}$ & $\begin{array}{c}\text { Coke rate, } \\
\mathrm{kg} / \mathrm{tHM}\end{array}$ & $\begin{array}{c}\text { Nut coke rate, } \\
\mathrm{kg} / \mathrm{tHM}\end{array}$ & $\begin{array}{c}\text { Coal rate, } \\
\mathrm{kg} / \mathrm{tHM}\end{array}$ & $\begin{array}{c}\text { Fe in } \\
\text { burden, \% }\end{array}$ \\
\hline 1 & Baosteel No. 1 & 2.00 & 1209 & 491 & 302 & 24 & 165 & 59.61 \\
\hline 2 & Baosteel No. 2 & 2.17 & 1235 & 486 & 285 & 26 & 175 & 60.02 \\
\hline 3 & Baosteel No. 3 & 2.00 & 1209 & 494 & 312 & 26 & 156 & 60.16 \\
\hline 4 & Baosteel No. 4 & 2.11 & 1253 & 489 & 289 & 26 & 174 & 59.65 \\
\hline 5 & Tisco No. 5 & 2.31 & 1140 & 520 & 330 & 7 & 183 & 59.43 \\
\hline 6 & Magang No. A & 2.17 & 1217 & 513 & 280 & 81 & 152 & 58.05 \\
\hline 7 & Magang No. B & 2.20 & 1220 & 507 & 277 & 85 & 145 & 58.11 \\
\hline 8 & Angang Bayuquan No. 1 & 1.82 & 1211 & 518 & 320 & 59 & 139 & 58.67 \\
\hline 9 & Bengang New No. 1 & 2.21 & 1243 & 529 & 316 & 59 & 154 & 59.42 \\
\hline 10 & Angang Bayuquan No. 2 & 1.90 & 1214 & 531 & 317 & 58 & 156 & 58.66 \\
\hline 11 & Shougang Jingtang Steel No. 1 & 2.26 & 1238 & 493 & 308 & 32 & 153 & 59.19 \\
\hline 12 & Wisco No. 8 & 2.70 & 1184 & 504 & 274 & 56 & 174 & 57.60 \\
\hline 13 & Shagang $5800 \mathrm{~m}^{3}$ & 2.22 & 1194 & 519 & 291 & 45 & 183 & 58.92 \\
\hline 14 & Shougang Qianan Steel No. 3 & 2.31 & 1244 & 514 & 308 & 42 & 164 & 58.41 \\
\hline 15 & Shougang Jingtang Steel No. 2 & 2.18 & 1216 & 500 & 317 & 31 & 152 & 58.72 \\
\hline 16 & Baosteel Meigang No. 5 & 2.17 & 1190 & 496 & 325 & 42 & 129 & 59.17 \\
\hline 17 & Anyang Steel No. 3 & 1.81 & 1200 & 504 & 317 & 37 & 150 & 58.93 \\
\hline 18 & Tisco No. 6 & 2.06 & 1172 & 568 & 384 & 13 & 171 & 59.38 \\
\hline
\end{tabular}

Note:

(1) Baogang No. 7 blast furnace was put into operation on May 27, 2014, there are no statistical data in 2013.

(2) The production of Magang No. A and No. B blast furnace in 2013 are not very normal, the data are for reference only. 


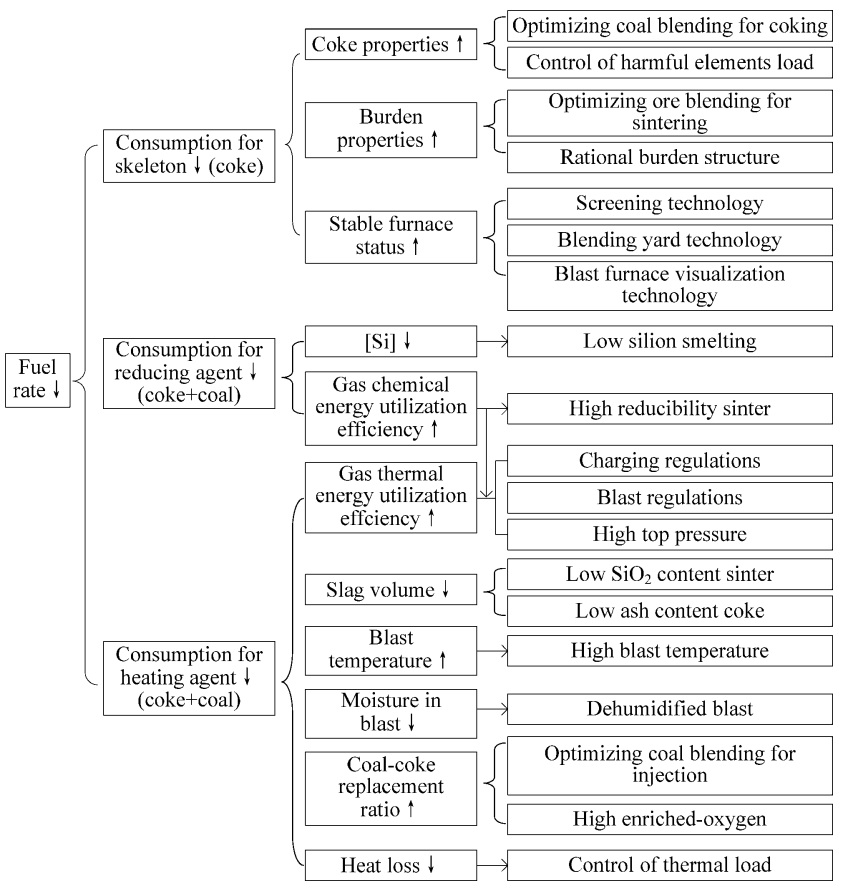

Fig. 3. Technical principle of low fuel rate operation of blast furnace.

(1) Increasing sinter basicity appropriately. For the amount of bonding phase will be decreased due to the reduction of $\mathrm{SiO}_{2}$ content, the binary basicity of sinter should be raised appropriately to increase the $\mathrm{CaO}$ content, thereby increase the content of calcium ferrite, which is beneficial to maintain necessary amount of bonding phase and improve the reducibility of sinter.

(2) Increasing the fine/nuclear ratio of sintering mixture appropriately. The bonding phase originates in small size fines, which can promote the solid phase reaction and the generation of sintering liquid phase.

(3) Optimizing iron ores matching. The type and characteristics of iron ores have important impact on the formation of calcium ferrite and consolidation of sintering mixture. Based on the grasp of sintering characteristics of iron ores, the suitable sintering phase can be formed by iron ores matching, which can satisfy the requirement of bonding phase amount for producing low $\mathrm{SiO}_{2}$ content sinter, and can also meet the requirement of high reducibility sinter.

(4) Raising the sintering layer thickness. Utilizing the self-regenerative effect of sintering layer, the solid fuel consumption and overall heat consumption can be reduced, thereby the sintering highest temperature drops, oxidizing atmosphere is strengthened, the $\mathrm{FeO}$ content of sinter decreases and the calcium ferrite content increases, the reducibility of sinter is improved, which is beneficial to the slather of limonite and improve the size composition of low $\mathrm{SiO}_{2}$ content sinter. At present, Magang sintering layer thickness can reach $900 \mathrm{~mm},{ }^{18}$ and the sintering layer thickness of Baosteel and Shougang Jingtang steel can reach $800 \mathrm{~mm}^{19,20)}$

According to statistical data of $\mathrm{SiO}_{2}$ content of sinter used in Chinese super-large blast furnaces in 2013, Baosteel and Tisco were less than $5 \%$, the rest were mainly concentrated in $5.0-5.5 \%$ except for Wisco (average $\mathrm{SiO}_{2}$ content of sinter was higher than $6.0 \%$ ).

\subsection{Optimizing the Coal Blending for Coking}

\subsubsection{Requirements of Coke Quality for Super-Large} Blast Furnace

The requirements of coke's skeleton role in lumpy zone and coke's permeability role in hearth are materially different as blast furnace volume is different. With the increase of blast furnace volume, hearth diameter grows, ore batch increases, coke load is aggravated, and thus the requirement of coke cold strength should be raised correspondingly. The activity of super-large blast furnace hearth has greater impact on yield, smooth operation, pulverized coal injection and tapping, thereby the higher requirements for alleviating the degradation of coke in blast furnace and ensuring the size of coke before tuyere and in deadman were put forward.

The practice of Baosteel showed that blast furnace resistance coefficient $\mathrm{K}$ can be reduced by about $8 \%$ as the $\mathrm{DI}_{15}^{150}$ of coke was improved from $86 \%$ to $87 \%$, thereby when the coal rate was improved from $120 \mathrm{~kg} / \mathrm{tHM}$ to $150 \mathrm{~kg} / \mathrm{tHM}$, about $40 \%$ of added value of permeability resistance of cohesive zone and dripping zone can be compensated for raising the $\mathrm{DI}_{15}^{150}$ of coke. The practice of pulverized coal injection showed that when coal rate was $150-180 \mathrm{~kg} / \mathrm{tHM}$, the $\mathrm{DI}_{15}^{150}$ of coke should be controlled at $85-88 \%, \mathrm{M}_{40}$ controlled at $86-87 \%$ and $\mathrm{M}_{10}$ controlled at $6-8 \%$ to meet the requirements of permeability. According to the coke reactivity test under different reaction time and the coke solution loss test under different coal rate, when the coal rate was improved from $150 \mathrm{~kg} / \mathrm{tHM}$ to $180 \mathrm{~kg} / \mathrm{tHM}$ or $200 \mathrm{~kg} / \mathrm{tHM}$, in order to overcome adverse effects brought by prolonged residence time and increased solution loss rate of coke, the CRI of coke should be controlled below $27 \%$ and the CSR should be controlled more than $64 \%$. If the CRI was controlled below $26 \%$ and the CSR controlled more than $66 \%$, it can meet the requirements of $200 \mathrm{~kg} / \mathrm{tHM}$ coal rate or higher. The coke quality with different coal rate of Baosteel and some other super-large blast furnaces are shown in Table 3. ${ }^{21)}$

\subsubsection{Coal Blending Practice for Coking}

With the expansion of Baosteel coking coal resources, the proportion of non-coking coal was raised gradually and has remained at about 5\%. Furthermore, Baosteel also successfully added weak caking coal with low ash content and low sulfur content, which effectively reduced the coke ash content and the coal blending cost. Baosteel basically achieved the stable coke composition with using more non-coking coal, adding weak caking coal and optimizing coal blending. In recent years, the quality of coal for coking fluctuated, in order to ensure the coke quality, Baosteel adjusted the coal blending structure for coking, raised the proportion of the strong caking coal (strong caking coal + quasi-strong caking coal), the coke quality was enhanced, among them $\mathrm{M}_{40}$ was raised to $90 \%, \mathrm{M}_{40}$ was reduced by about $0.5 \%$, the ash content of coke was controlled less than $12 \%$, average size was over $52 \mathrm{~mm}^{22}$ ) The overall improvement of coke quality provided a strong support for enhancing the blast furnace indexes. Figure 4 shows the change of coal blending structure for coking since Baosteel blast furnaces were put into operation.

Based on the characteristics and contribution to coke thermal property of different coals for coking, Wisco estab- 
Table 3. Coke quality with different coal rate of Baosteel and some other super-large blast furnaces.

\begin{tabular}{cccccccccc}
\hline $\begin{array}{c}\text { Coal rate, } \\
\mathrm{kg} / \mathrm{tHM}\end{array}$ & $\begin{array}{c}\mathrm{DI}_{15}^{150} \% \\
\%\end{array}$ & $\mathrm{~A}_{\mathrm{d}}, \%$ & $\mathrm{TS}, \%$ & $\mathrm{M}_{40}, \%$ & $\mathrm{M}_{10}, \%$ & $\mathrm{CRI}, \%$ & $\mathrm{CSR}, \% \begin{array}{c}\mathrm{MS}, \\
\mathrm{mm}\end{array}$ \\
\hline $170-190$ & 87.78 & 11.37 & 0.47 & 89.74 & 5.19 & 23.50 & 71.40 & 51.79 \\
$200-220$ & 88.06 & 11.36 & 0.46 & 89.54 & 5.23 & 23.93 & 70.64 & 52.96 \\
$230-260$ & 88.75 & 11.35 & 0.46 & 90.13 & 5.17 & 24.35 & 70.69 & 53.32
\end{tabular}

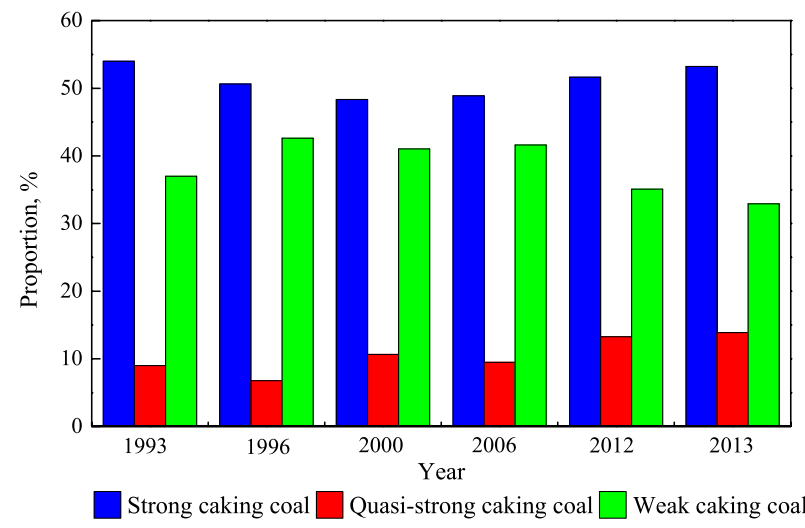

Fig. 4. Coal blending structure for coking since Baosteel blast furnaces were put into operation. (Online version in color.)

lished the evaluation and application system of coals for coking considering coke microstructure index, rheological property and process indexes, replaced high-price fat coal by combination of $1 / 3$ coking coal's coking microstructure and gas-fat coal's expansibility and cohesiveness, substituted $10-23 \%$ lean coal $(\mathrm{G}>10-30)$ for high quality lean coal, the proportion of fat coal and coking coal reduced from $60-80 \%$ to below $40 \%$, the proportion of meager-lean coal reached $16-23 \%$ by appropriately crushing meager-lean coal to change the occurrence state, thus built coal blending technology to produce high quality coke and improve the yield of metallurgical coke, gained the low cost coal blending structure for super-large coke oven with $7.63 \mathrm{~m}$-width coking chamber, which contained no fat coal, $28-38 \%$ coking coal and $14-23 \%$ meager-lean coal. ${ }^{23,24)}$ As shown in Table 2, high quality coke was the key factor for low fuel rate operation of Wisco No. 8 blast furnace with low Febearing grade burden.

\subsection{Blending Yard Technology}

The fluctuation of Fe content and slag basicity will cause unsteady status in blast furnace, thus make coke rate rise and output decline. Chinese modern steel enterprises with super-large blast furnace all built own raw material yard to conduct storage, blending and bulk handling to reduce the composition fluctuation of mixing ore, sinter or pellet. The raw materials can be conducted in water management and size management according to the utilization requirement, and the varieties and proportion of raw material can be adjusted according to production requirement of blast furnace, to adapt to changes in supply of raw materials. Baosteel developed the mixing ore intelligent stacking model, by programming the general plan of mixing ore, dynamic allocation of raw materials into dosing tanks, and intelligent control of the cutting velocity of constant feed weighers, to ensure uniform composition of mixing ore in stacking

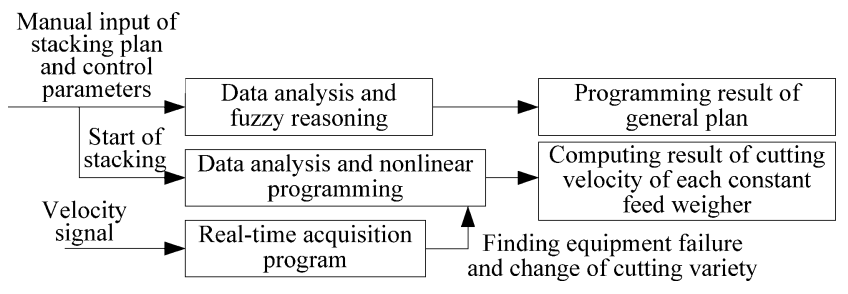

Fig. 5. Function chart of mixing ore intelligent stacking model of Baosteel blending yard.

process, finally the standard deviation of mixing ore reached $\delta_{\mathrm{SiO}_{2}}= \pm 0.124, \delta_{\mathrm{TFe}}= \pm 0.376$, which lay the foundation for the blast furnace concentrate, as shown in Fig. 5. ${ }^{25)}$

\subsection{Control of Harmful Elements Load}

The accumulation of harmful elements would damage refractory lining, leading to frequent fluctuation of thermal load and unstable furnace status. Particularly, the harmful elements would cause coke degradation, destroy the skeleton function of coke, resulting in higher coke rate. The research of Shougang Jingtang steel found that under alkali load was $4 \mathrm{~kg} / \mathrm{tHM}$ and zinc load 250-300 g/tHM, the degradation rate of coke size located at $0.5-2.5 \mathrm{~m}$ before tuyere was about $65-75 \%$, the coke was damaged severely. In recent years, Chinese super-large blast furnace operators have paid special attention to the damaging effect of harmful elements for coke and implemented the strict harmful elements charging control standard. Currently Baosteel's control standard is: $\mathrm{K}_{2} \mathrm{O}+\mathrm{Na}_{2} \mathrm{O}$ load less than $2 \mathrm{~kg} / \mathrm{tHM}$, $\mathrm{Zn}$ load less than $150 \mathrm{~g} / \mathrm{tHM}$.

\subsection{Screening Technology}

Blast furnace is belong to a vertical moving bed and has a high request for permeability to maintain smooth operation. The charging fines should be controlled by necessary screening of burden and hardworking management of screen mesh for low fuel rate operation. The proportion of burden less than $5 \mathrm{~mm}$ shouldn't exceed 3-5\%. The reduction of charging burden less than $5 \mathrm{~mm}$ can also reduce the amount of dust. Every $1 \%$ charging fines decreases, coke rate decreases by $0.5 \%{ }^{21)}$

\subsection{Utilization of Small Size Sinter}

The utilization of small size sinter can increase the agglomeration ratio, and create conditions to reduce fuel rate. In addition, the utilization of small size sinter can reduce secondary return fines, thus reduce the fuel consumption in sintering. The sinters of Wisco were divided into two range according to the size: $>11 \mathrm{~mm}$ and $3.5-11 \mathrm{~mm}$, and the $3.5-11 \mathrm{~mm}$ sinters were charged at the edge of throat, then both the utilization efficiency of sinter and gas were raised, the fuel rate was reduced. ${ }^{26)}$ Currently, Shougang Jingtang steel recycles the 3-8 $\mathrm{mm}$ sinter, and the utilization efficiency of burden is improved. ${ }^{27,28)}$

\subsection{Utilization of Nut Coke}

Nut coke is undersized coke of screen under coke silo of blast furnace, generally less than $25 \mathrm{~mm}$. Except for using as fuel in sintering, nut coke can also be utilized in blast furnace by ore-coke mixed charging to improve the utilization of energy for ironmaking. The practice of Baosteel showed 
that using a certain proportion of nut coke was beneficial to smooth operation and had distinct effect on reducing fuel rate. The trend of nut coke utilization in Baosteel is shown in Fig. 6.

In addition to using nut coke, Wisco also recycled coke breeze from coking plant, the screen mesh is $10 \mathrm{~mm}$, and the size of coke breeze is $10-15 \mathrm{~mm}$. Since August 2011, Wisco No. 8 blast furnace began to utilize recycled coke breeze to improve permeability and gas utilization efficiency, finally the effect to reduce fuel rate was very obvious, and currently the consumption of recycled coke breeze has reached $20 \mathrm{~kg} / \mathrm{tHM}$.

\subsection{Injection of CDQ Dust}

Baosteel coking plant adopted dry quenching process, thus the calorific value of CDQ dust (coke dry quenching) is significantly higher than coal. By adjusting the pulverizing and injecting operation technology, the CDQ dust was added into raw coal, then pulverized and injected into blast furnace, the highest monthly average can reach $4.96 \mathrm{~kg} / \mathrm{tHM}$.

Wisco No. 8 blast furnace added $8 \%$ CDQ dust into raw coal to replace anthracite, then the proportion of anthracite was gradually decreased from $50 \%$ to the current $30 \%$. Finally the fixed carbon content of injection coal was increased and coke rate was reduced. ${ }^{29)}$

\section{Improving Gas Utilization Efficiency}

In blast furnace, various processes are conducting under the condition of constant burden-gas reverse movement. Therefore, the smoothly downward burden and rational distribution of gas flow is a sign of smooth operation and preconditions for improving gas utilization efficiency and reducing fuel rate. Improvement of gas utilization efficiency can fully utilize the gas thermal- and chemical- energy, thus reduce fuel rate. The gas utilization efficiencies of Chinese super-large blast furnaces are generally high, among them Baosteel is the highest (close to $52 \%$ ).

When the conditions of blast furnace smelting and raw materials are determined, burden distribution becomes the primary means to adjust gas flow distribution.

\subsection{Upper Adjustment}

The purpose of selecting charging regulations is to control the radial ore/coke at throat and realize rational gas flow

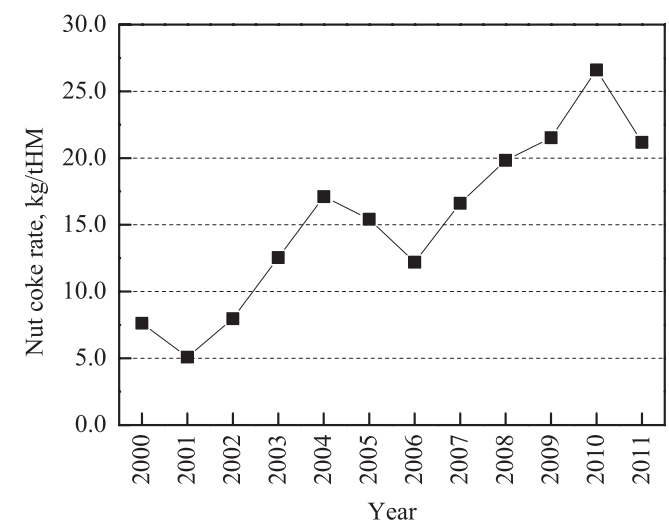

Fig. 6. Trend of nut coke utilization in Baosteel blast furnaces. distribution, and the charging regulations include charging mode, batch weight and stock line level.

\subsubsection{Charging Mode}

Charging regulations have two main modes: platform plus funnel and central coke charging. From the perspective of improvement of gas utilization efficiency, bell-less top charging usually adopts platform plus funnel, which intensively considers the width of coke platform, the width of ore platform and the depth of funnel. In actual production, the width of ore platform and the width of coke platform are generally about $1 / 3$ of throat radius, and the width of coke platform is slightly larger than the width of ore platform. When the coal rate raises, the ore/coke increases, the weight of coke batch decreases, the coke window narrows, and the ore/coke at the edge of lumpy zone increases, thus the gas flow distribution is affected, leading to deterioration of permeability and increase of pressure difference. Thereby, the depth of central funnel should be increased to adjust the central gas flow, while the edge should be relaxed properly by increasing coke amount or decreasing ore amount. Overall, the mode of platform plus funnel needs to determine the width of coke platform, the coke amount in central funnel and the ore amount rolling to the center, to avoid the obstruction of central gas flow, deterioration of smooth operation, and increase of fuel rate. The width of coke platform and depth of central funnel should be determined according to blast furnace's own production conditions.

With the blast furnace enlarging, the smelting period extends, the degradation of coke is more serious, the gas flow increases. As the cross sectional area is expanding, the volume of deadman increases, the uniformity of gas flow distribution worsens, so it need to strengthen the central gas flow, increase the height of inverted-"V"-shaped cohesive zone to ensure the enough area of coke window and smooth gas flow. The mode of central coke charging can enhance and stabilize the central gas flow, reduce the solution loss of central coke, prevent the degradation of coke, appropriately increase the height of inverted-"V"-shaped cohesive zone, and ensure the rational gas flow distribution and smooth operation. Therefore, the super-large blast furnace could adopt central coke charging mode when necessary, but at the same time should pay attention to avoid overdose.

The biggest advantages of platform plus funnel mode are higher gas utilization efficiency and lower fuel rate, but its requirement of stability of raw material quality is higher. While the biggest advantages of central coke charging mode is better to adapt the fluctuation of raw material quality, but the biggest drawback is lower gas utilization efficiency and higher fuel rate. For Chinese super-large blast furnaces, the gas utilization efficiencies of platform plus funnel mode are generally $50.5-52.5 \%$, and the one of central coke charging mode are generally $46.5-48.5 \%$, a difference of two modes usually around $4 \%$, as converted into fuel rate is about $20 \mathrm{~kg} / \mathrm{tHM}$.

\subsubsection{Batch Weight}

The weight of ore batch has much impact on the burden distribution at throat, and has some influence on the gas flow distribution, for different blast furnace there is an appropriate control range. With the increase of blast furnace volume, 
the throat area increases correspondingly, the weight of ore batch should be expanded accordingly. The ore batch weight of Shagang $5800 \mathrm{~m}^{3}$ blast furnace expanded gradually with the strengthening operation, from about $120 \mathrm{t}$ per charge at the early blow-in to currently $170 \mathrm{t}$ per charge, which reached the design limit of hopper. Shougang Jingtang steel No. 1 blast furnace and No. 2 blast furnace realized the large ore batch operation respectively by expanding hopper and "ore-ore-coke" operation, the ore batch weight was increased from $140 \mathrm{t}$ per charge to about $180 \mathrm{t}$ per charge. The large ore batch is beneficial to stabilize furnace status, improve gas utilization efficiency and reduce fuel rate. ${ }^{27)}$

From the perspective of stabilizing coke layer in cohesive zone and reducing the change of gas flow distribution, the upper adjustment in production should stabilize the coke batch weight thus change ore batch accordingly. Baosteel's requirement of coke layer depth is: not less than $0.50 \mathrm{~m}$ at throat and not less than $0.20 \mathrm{~m}$ at belly. ${ }^{30)}$

\subsubsection{Stock Line Level}

The adjustment of stock line level is adjusting the falling height of burden to change the position of depositing peak, and in conjunction with the initial angle of chute. With the different stock line level, the burden distribution at the surface is different, leading to great influence on gas flow distribution. The stock line level relates to the profile of throat, profile of upper shaft and burden properties. In practice, the control of stock line level should be combined with bell-less charging angle, and the initial falling point should be located within $300 \mathrm{~mm}$ from wall. ${ }^{21)}$

\subsection{Lower Adjustment}

To match the upper adjustment, the lower adjustment is by adjusting the blast parameters to control the status of tuyere combustion zone and initial distribution of gas flow distribution, it is the key to control smooth operation, rational gas flow distribution and improvement of gas utilization efficiency. A rational initial gas flow distribution can be formed by lower adjustment.

\subsubsection{Control of Blast Volume}

When the bosh gas volume is small, with the increase of blast volume and strengthening of blast furnace, fuel rate and coke rate will decrease. As the blast furnace is strengthened to a certain extent, the bosh gas volume is restricted, if increasing blast volume unceasingly, fuel rate and coke rate will increase. Because the gas flow is affected by the permeability of stock column, leading to developmental peripheral gas flow or excessive reinforced central gas flow, so the gas utilization efficiency decreases and fuel rate increases. The super-large blast furnace should control moderate blast volume to ensure rational gas distribution, improve gas utilization efficiency and reduce coke rate and fuel rate.

\subsubsection{Control of Blast Kinetic Energy}

With the change of production conditions, in order to achieve optimal or near optimal depth of raceway, and rational initial gas flow distribution, the tuyere area is adjusted properly to maintain appropriate wind velocity and blast kinetic energy, to avoid the influence of excessively high wind velocity and blast kinetic energy on coke in raceway.
Currently, the blast kinetic energy of Chinese super-large blast furnaces is general $14000-15000 \mathrm{~kg} \cdot \mathrm{m} / \mathrm{s}$, to achieve this goal, the first measure is to maintain a reasonable wind velocity, and the value is general $250-270 \mathrm{~m} / \mathrm{s}$. If the coke strength is high, the wind velocity can be higher, and vice versa. In recent years, the wind velocity has a tendency to ceiling by matching blast volume, tuyere area, blast temperature, and top pressure reasonably, thereby achieved good production indexes. ${ }^{31)}$

\section{Comprehensive Blast Technology}

\subsection{High Blast Temperature}

The heat required for blast furnace mainly comes from combustion of fuel and physical heat of hot blast, and the latter accounts for about $30 \%$ of the total heat. The more the physical heat brought by hot blast, the lower the required heat from fuel combustion. Improving blast temperature can reduce fuel rate and save the ironmaking cost, one reason is that physical heat brought by hot blast can replace some fuel; the other reason is that with the increase of blast temperature, the coal rate can be improved to replace some coke, and thus the coke rate can be reduced.

In recent years, Chinese hot blast stove technology has gained a significant development, the type of hot blast stove developed from internal-combustion to externalcombustion, and then to top-combustion; the fuel gas changed from low calorific value blast furnace gas with enriching part of high calorific value gas to full blast furnace gas with gas-air double preheating technique, thereby the blast temperature is increasing year by year. The blast temperature of some Chinese super-large blast furnaces have reached above $1250^{\circ} \mathrm{C}$, achieving the world-class level. In 2009, Shougang Jingtang steel $5500 \mathrm{~m}^{3}$ blast furnace successfully adopted the BSK top-combustion type hot blast stove, which has independent intellectual property rights on the basis of Kalugin patented technology of hot blast stove, by burning full blast furnace gas and adopting gas-air double preheating technique, the average monthly blast temperature reached $1300^{\circ} \mathrm{C}$ in March 2010 .

\subsection{Dehumidified Blast}

The dehumidified blast technology can reduce heat absorption of water decomposition, raise the flame temperature, promote injecting coal, thereby reduce coke rate. Generally, every $1 \mathrm{~g} / \mathrm{Nm}^{3}$ moisture in blast is removed, coke rate decreases by $0.8-1 \mathrm{~kg} / \mathrm{tHM}$. From the perspective of maintaining hearth thermal state, every $1 \mathrm{~g} / \mathrm{Nm}^{3}$ moisture in blast is removed, coal rate increases by $1.5-2.0 \mathrm{~kg} / \mathrm{tHM}^{21)}$

Baosteel blast furnaces' operating principles are high blast temperature and low blast humidity, by adjusting the coal injecting amount to control furnace temperature, the blast temperature was stabilized at $1230-1250^{\circ} \mathrm{C}$, and the moisture in blast was stabilized at $10-15 \mathrm{~g} / \mathrm{Nm}^{3}$. The moisture in blast of Shagang $5800 \mathrm{~m}^{3}$ blast furnace was controlled at $15-17 \mathrm{~g} / \mathrm{Nm}^{3}$.

\subsection{High Top Pressure}

Improving the top pressure can reduce the gas flow velocity, lower the pressure loss of stock, and promote smooth operation. In addition, the increase of top pressure can 
reduce the dust amount, raise the utilization efficiency of coke and coal, reduce the fuel rate and coke rate. ${ }^{32)}$

At present, improving the top pressure has become an indispensable means for normal production of blast furnace. The top pressure of Shougang Jingtang steel $5500 \mathrm{~m}^{3}$ blast furnace is about $270 \mathrm{kPa}$, and that of Shagang $5800 \mathrm{~m}^{3}$ blast furnace has reached $285 \mathrm{kpa}$, which is a higher level in the same type of blast furnace. The trend of Shagang $5800 \mathrm{~m}^{3}$ blast furnace top pressure and oxygen enrichment rate since blow-in is shown in Fig. 7.

\subsection{Economic Coal Injection}

The purpose of coal injection is to save coke farthest and reduce ironmaking cost. Despite there is a price difference between coal and coke, if the coal-coke replacement ratio decreases to a certain degree, the fuel rate will increase, and the economic benefits brought by the coal injection will be offset, therefore in recent years Chinese blast furnaces are implementing the economic coal injection gradually, a high replacement ratio must be maintained while increasing the coal injecting amount, and no longer blindly pursuing high coal rate. The prerequisites for the implementation of economic coal injection are:

(1) Improving the quality of burden, including coke, sinter, pellet and lump ore, to reduce slag volume and improve permeability in upper and lower blast furnace.

(2) Implementation of high enriched-oxygen, high blast temperature and dehumidified blast technology to control the flame temperature and accumulated amount of unburned pulverized coal and coke powder in hearth, increase the combustion rate of pulverized coal. Oxygen enrichment can reduce gas volume per ton iron hot metal, increase the flame temperature, and change the temperature distribution in blast furnace. Combining oxygen enrichment with coal injection appropriately can reduce the change of heat flow ratio, maintain the flame temperature in a reasonable scope, and make the blast furnace in a stable status. Every $1 \%$ oxygen enrichment rate increases, the coal combustion rate increases by $1.51 \%$. High enriched-oxygen is a characteristic of Shagang $5800 \mathrm{~m}^{3}$ blast furnace, and the oxygen enrichment rate was more than $10 \%$ (as shown in Fig. 7), ${ }^{33}$ ) which set a precedent of high enriched-oxygen in Chinese super-large blast furnace, and especially compensated the shortage of Shagang coke quality.

(3) Rational gas flow distribution and stable furnace

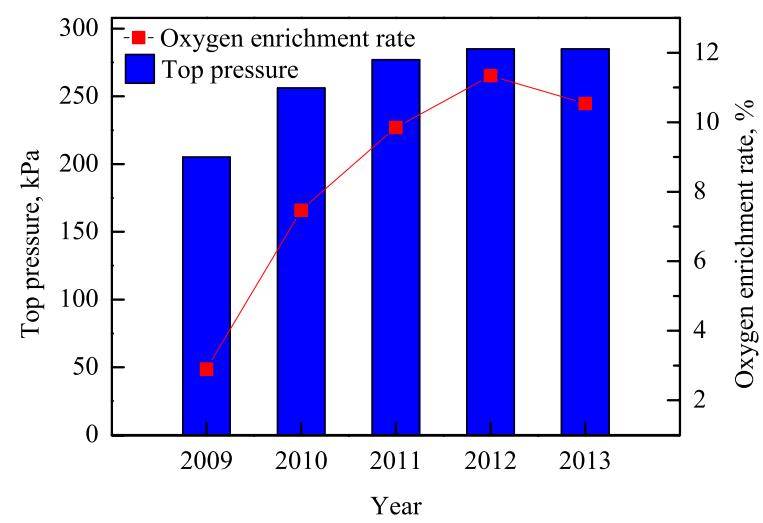

Fig. 7. Trend of Shagang $5800 \mathrm{~m}^{3}$ blast furnace top pressure and oxygen enrichment rate. (Online version in color.) status. Appropriate central gas flow in lower blast furnace should be ensured by adjusting the blast parameters, and then the unburned pulverized coal entered into hearth can be utilized fully, finally the utilization efficiency of coal increases.

(4) Optimizing the coal blending for injection can improve the combustion property of mixed coal, raise the coal rate, expand the options of coal type, and reduce the cost of mixed coal. Generally the anthracite with high fixed carbon content and high calorific value is matched with bituminite with high volatile matter content and good combustion property, finally the volatile matter content of mixed coal should be controlled at $15-25 \%$, and the ash content should be lower than that of coke (generally should not exceed $11 \%$ ). Shagang $5800 \mathrm{~m}^{3}$ blast furnace has raised bituminite proportion from highest $43 \%$ to highest $54 \%$.

For a long time, Baosteel blast furnaces persisted in high coal rate operation to reduce the consumption of coke, but with further increase of coal rate, on the contrary, the fuel rate would increase due to the decrease of coal combustion rate and replacement ratio. Currently, with the price rising and quality degrading of raw material, Baosteel blast furnaces begin to seek reasonable and economic coal rate. The trend of Baosteel blast furnace coal rate is shown in Fig. 8. ${ }^{34)}$

\section{Low Silicon Smelting}

Implementation of low silicon smelting contributes to reduction of fuel rate. Every $0.1 \%$ [Si] decreases, fuel rate could reduce by $4-6 \mathrm{~kg} / \mathrm{tHM}$. The hearth of super-large blast furnace is active and has plenty of heat, so it is easy to achieve low silicon smelting. The main techniques include:

(1) Reduction of $\mathrm{SiO}_{2}$ charging load by decreasing coke ash content, coal ash content and sinter $\mathrm{SiO}_{2}$ content. Though China is limited by the characteristics of the coking coal resources (high ash content and low sulfur content of coking coal and fat coal), with the constant progress of coal blending technology for coking, the ash content of coke used for super-large blast furnaces of Baosteel, Tisco, Shougang, Angang, and etc. was lower than $12 \%$.

(2) Under the prerequisites of guaranteeing plenty hearth heat and smooth operation, the flame temperature could be reduced appropriately to restrain the generation of $\mathrm{SiO}$ gas.

(3) Controlling reasonable shape and position of cohesive zone to reduce the contact of dripping molten iron with $\mathrm{SiO}$

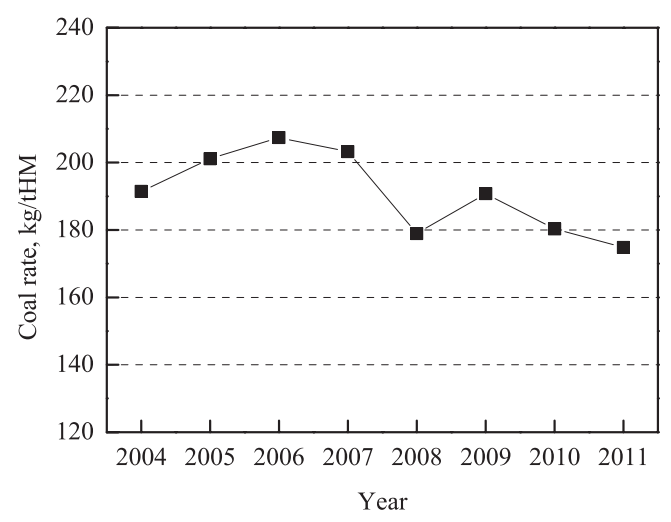

Fig. 8. Trend of Baosteel blast furnaces' coal rate. 
gas, thus the generation of [Si] is inhibited.

(4) Optimizing the performance of slag to reduce the activity of $\mathrm{SiO}_{2}$ in slag.

(5) Implementation of high top pressure operation to suppress the generation of $\mathrm{SiO}$ gas.

However, it should be noted the impact of low silicon smelting on campaign life of blast furnace, such as the erosion of hearth lining would be exacerbated. Thereby China has begun to no longer advocate low silicon smelting, and the desilication before furnace or desilication in steelmaking process is mostly conducted. The average [Si] of Baosteel blast furnaces reduced from $0.5-0.6 \%$ in the early blow-in to about $0.35 \%$, the lowest average monthly [Si] of No. 3 blast furnace has reached $0.28 \%$, but since 2008 , due to the increase of hearth lining temperature and implementation of furnace protection operation, the [Si] was controlled higher gradually, the trend of Baosteel blast furnaces' [Si] is shown in Fig. 9.

\section{Control of Thermal Load}

The heat loss of blast furnace was reduced mainly by controlling the thermal load of lining. The thermal load reflects the cooling status of each part of lining, so it is often used to judge the development of peripheral gas flow and working status of lining. Thermal load should be controlled within a certain range, and as far as possible to reduce the heat loss, which is helpful to reduce fuel rate. However too low thermal load may cause thickening of lining, then affect gas flow distribution and furnace status; on the contrary, while the slag skull falls off, the furnace status is also affected, even the tuyere would be smashed, leading to reducing blast or blow-off. Therefore, control of rational thermal load is beneficial to stabilize furnace status and reduce fuel rate.

To preserve the appropriate thermal load in daily operation, one measure is maintaining the rational gas flow distribution by adjusting the charging regulation; the other is adjusting cooling water flow according to the erosion status and temperature of lining, to maintain stable slag skull and operation profile. Thereinto, the adjustment of gas flow distribution is the most important means.

In the operation of Baosteel blast furnace, thermal load is implemented partition management along height and circumference direction, the management standard of different height area is different, and the thermal load along circumference direction should be keep uniform. The control of

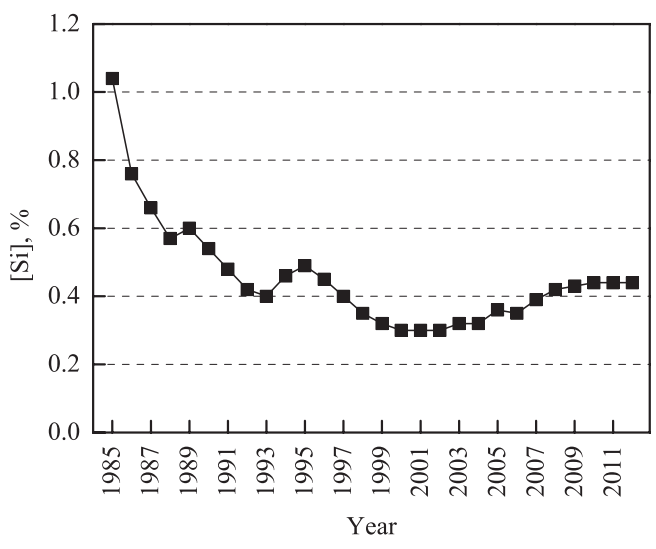

Fig. 9. Trend of Baosteel blast furnaces' [Si]. thermal load is changing from upper adjustment and lower adjustment to gradually emphasize the middle-part management of blast furnace (between lower shaft and bosh).

The three-dimensional visualization thermal load model of Shougang Jingtang steel No. $15500 \mathrm{~m}^{3}$ blast furnace has developed by Shougang and University of science and technology Beijing, which realized 3D real-time display of thermal load, historical trend video-query, and alarm function, as shown in Fig. 10. Combining the model with profile management model could determine the reasonable control range of thermal load and provide guidance for blast furnace operation.

\section{Blast Furnace Visualization Technology}

Since the 21st century, University of science and technology Beijing and Shenwang Pioneer Tech. Corporation Beijing developed blast furnace visualization technology. The technology can be used to monitor burden distribution and furnace status, help operator intuitively understand in-furnace status and charging effect, change the passive operation to active operation, make the visual manipulation as possible, avoid accidents, improve gas utilization efficiency, reduce fuel rate, finally maintain long-term smooth operation. $^{35)}$

\subsection{Blast Furnace Top Video Camera (CCD), Thermal Camera (FPA) and Image Processing Technology}

By using the top video camera (CCD), operators can online observe chute movement, gas flow distribution and burden stream throughout the whole burden surface, and monitor the abnormal furnace status, such as tunnel and slip. With the enlarging of blast furnace and improvement of operating level, the top temperature decreases gradually, then the existing video camera (CCD) can't work normally with top temperature less than $120^{\circ} \mathrm{C}$, therefore, the thermal camera (FPA) was developed subsequently. Shagang $5800 \mathrm{~m}^{3}$ blast furnace installed top video camera and thermal camera simultaneously, as shown in Fig. 11. ${ }^{36}$ )

\subsection{Online Measurement of Burden Surface Profile with Laser Technology}

Online measurement of burden surface profile with laser technology is by installing the blast furnace burden surface laser detector to obtain the visual burden surface profile image while the blast furnace is in production, as shown in Fig. 12.

\subsection{Blast Furnace Tuyere Video Camera and Image Processing Technology}

By using the tuyere video camera, operators can simultaneously observe the brightness, coke movement and coal stream size of each tuyere, and timely detect the sliding of slag skull and cold burden in front of the tuyere. By subsequently image processing, operators can gain the quantitative analysis of thermal state and coal stream status of each tuyere, thereby understand the working status of tuyere and coal injection system timely and comprehensively. In addition, the new type tuyere video camera was assembled a spectroscope, operators can still directly observe the tuyere through the peephole. The 40 tuyeres of Shagang $5800 \mathrm{~m}^{3}$ 


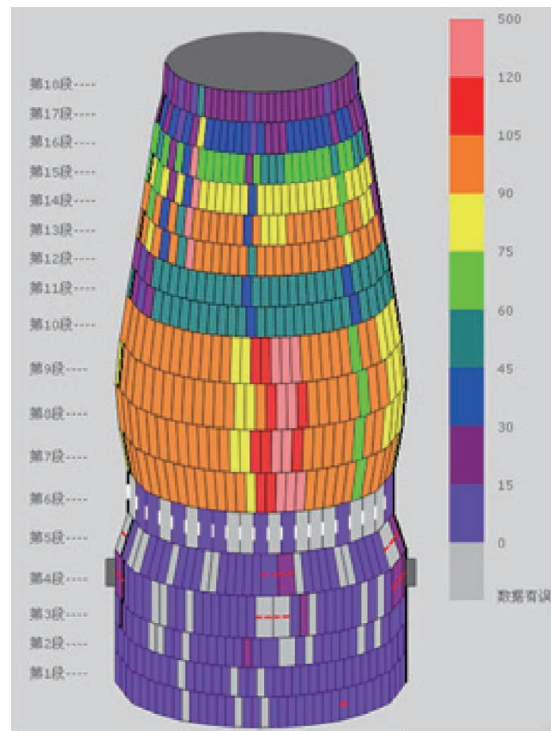

Fig. 10. Three-dimensional visualization thermal load model of Shougang Jingtang steel No. $15500 \mathrm{~m}^{3}$ blast furnace.

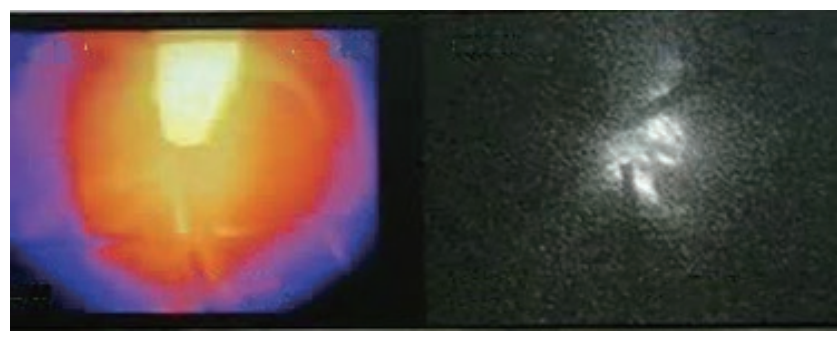

(a) Top thermal camera image (b) Top video camera image Fig. 11. Shagang $5800 \mathrm{~m}^{3}$ blast furnace top camera image.

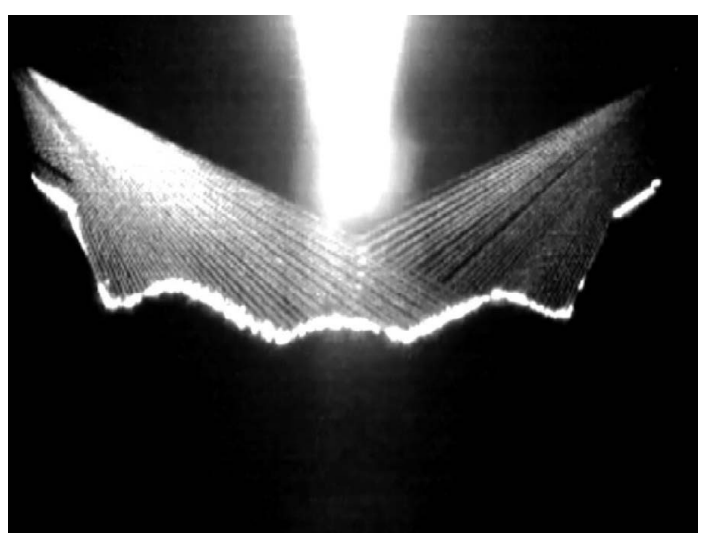

Fig. 12. Online blast furnace burden surface profile with laser technology.

blast furnace were all installed the new type tuyere video cameras, as shown in Figs. 13 and 14.

\subsection{Filling Study with Laser Technology}

By using laser technology to conduct blow-in filling measurement, the data of burden flow trajectory with different angle of chute and the data of burden surface profile after charging could be obtained, furthermore, the burden distribution law of charging device could be gained and used

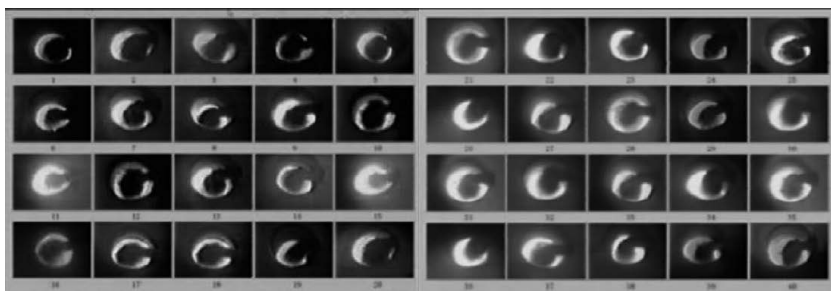

Fig. 13. Shagang $5800 \mathrm{~m}^{3}$ blast furnace tuyere images.

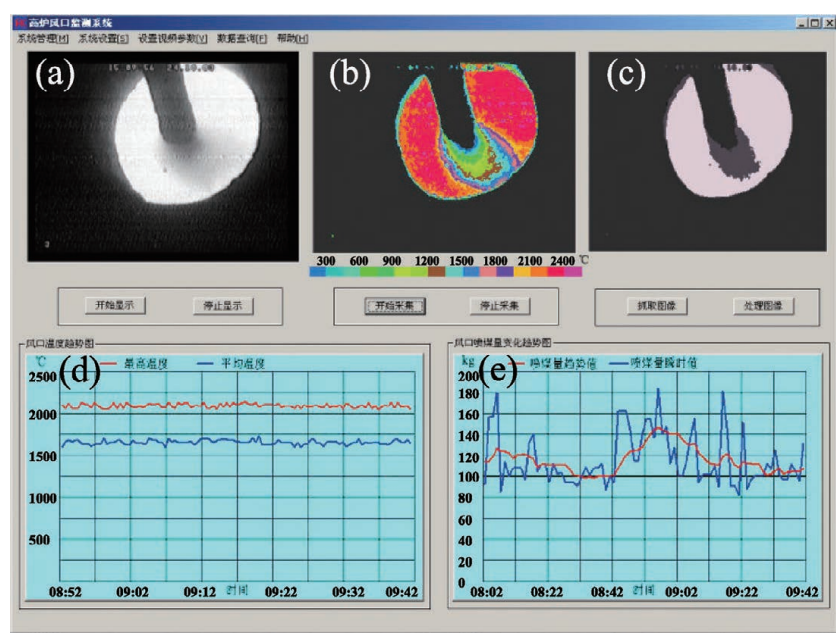

Fig. 14. Interface of tuyere images processing. Note: (a) is the original image of tuyere video camera. (b) is the colorful image after processing, by using different colors represent different temperature. (c) is the gray image after processing. (d) is the trend of temperature of tuyere, $\mathrm{X}$ axis is time, $\mathrm{Y}$ axis is temperature; Red line represents the highest temperature, and blow line represents the average temperature. (e) is the trend of coal rate of tuyere, $\mathrm{X}$ axis is time, $\mathrm{Y}$ axis is coal rate; Red line represents the trend value of coal rate, and blow line represents the instantaneous value of coal rate.

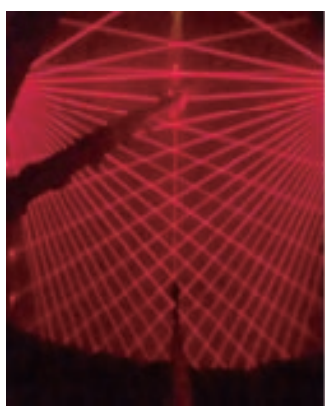

(a) Laser grid

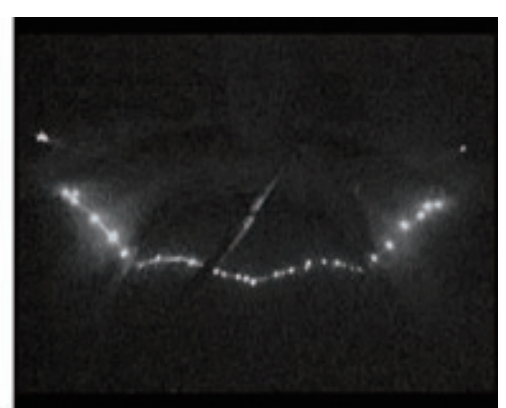

(b) Burden surface image
Fig. 15. Laser grid and burden surface image in blast furnace.

to guide the charging operation of blast furnace after commission, as shown in Fig. 15. In recent ten years, Chinese super-large blast furnaces were all used laser grid method to conduct blow-in filling measurement. ${ }^{37}$

\section{Conclusions}

(1) The development of Chinese super-large blast furnace started late, there are 19 super-large blast furnaces 
more than $4000 \mathrm{~m}^{3}$ running in China currently, among them there are 3 blast furnaces more than $5000 \mathrm{~m}^{3}$, by Chinese super-large blast furnace operators' continuous efforts, significant progresses in low carbon operation have been obtained, and then fuel rate was declined ceaselessly, The design, equipment manufacturing, operation and management technologies of Chinese super-large blast furnace have reached the world advanced level.

(2) In terms of raw materials preparation, low carbon operation technologies include producing low $\mathrm{SiO}_{2}$ content and high reducibility sinter to reduce slag volume and improve sinter metallurgical properties; optimizing coal blending structure for coking to guarantee the coke quality; implementing blending yard technology to stabilize blast furnace operation; controlling harmful elements load to reduce their damage to coke; adopting screening technology to reduce dust amount; recycling small size sinter, nut coke and CDQ dust to improve ironmaking energy efficiency.

(3) In terms of blast furnace operation, low carbon operation technologies include improving gas utilization efficiency by upper adjustment and lower adjustment, the upper adjustment including charging mode, batch weight and stock line level, lower adjustment including the control of blast volume and blast kinetic energy; implementing comprehensive blast technology of high blast temperature, dehumidified blast and high top pressure, promoting economic coal injection concept; conducting low silicon smelting, but should pay attention to its impact on the campaign life of blast furnace; controlling thermal load to reduce heat loss, emphasizing the middle-part management of blast furnace; development and application of blast furnace visualization technology to guarantee the long-term smooth operation of blast furnace.

\section{Acknowledgements}

This work was supported by the National Science Fund for Distinguished Young Scholars (Grant No. 51304014).

\section{REFERENCES}

1) Q. Zhang, G. Y. Jia, J. J. Cai and F. M. Shen: J. Northeastern Univ.
(Nat. Sci.), 34 (2013), 392.

2) Z. Y. Xiang and Z. P. Zou: China Steel, 8 (2010), 9

3) H. B. Zuo, J. L. Zhang and X. L. Wang: Iron Steel, 47 (2012), 86.

4) Y. Ujisawa, K. Nakano, Y. Matsukura, K. Sunahara, S. Komatsu and T. Yamamoto: ISIJ Int., 45 (2005), 1379.

5) S. Ueda, T. Miki, T. Murakami, H. Nogami and T. Sato: Tetsu-toHagané, 99 (2013), 1.

6) Z. J. Liu, J. L. Zhang, H. B. Zuo and T. J. Yang: ISIJ Int., 52 (2012), 1713.

7) Z. J. Liu, J. S. Jin and B. K. Hu: Baosteel Technol., 15 (1997), 5.

8) X. B. Hu and T. Q. Wang: Iron Steel Technol., 40 (2011), 5.

9) T. Q. Wang, C. C. Lin, B. Xiong, J. Q. Ma and X. P. Xia: Ironmaking, 33 (2014), 13.

10) C. C. Lin and Z. Y. Xiang: Baosteel Technol., 27 (2009), 49.

11) R. L. Zhu and Y. M. Chen: Ironmaking, 24 (2005), 9.

12) T. Q. Wang, H. Y. Zhu, Q. Z. Ju and X. P. Xia: Ironmaking, 31 (2012), 27.

13) T. J. Yang: Proc. 2014 Natl. Iron Production \& Technology and Annual Ironmaking Conf., CSM, Beijing, (2014), 1.

14) W. G. Li: Baosteel Technol., 32 (2014), 1.

15) W. G. Li: World Met., 51 (2013), 1.

16) Q. Liu: China Steel Focus, 24 (2011), 45.

17) R. L. Zhu: Baosteel Technol., 26 (2008), 1.

18) B. Zhang: Sintering Pelletizing, 39(2014), 15.

19) X. M. Mao, T. Zhu and J. F. Li: Ironmaking, 24 (2005), 99.

20) H. J. Wang, G. An, Q. L. Wang and F. K. Shi: Sintering Pelletizing, 35 (2010), 47.

21) Z. Y. Xiang and X. L. Wang: Blast Furnace Design-Ironmaking Process Design Principles and Practices, 2nd Ed., Metallurgical Industry Press, Beijing, (2014), 124.

22) J. M. Zhu and C. Wang: Proc. 2014 Natl. Iron Production \& Technology and Annual Ironmaking Conf., CSM, Beijing, (2014), 129.

$23)$ G. F. Xue, R. Xiang, P. Chen and S. C. Liu: J. Wuhan Uni. Sci. Technol., 32 (2009), 36

24) R. Xiang, Z. K. Song, G. F. Xue and J. F. Bao: J. Wuhan Uni. Sci. Technol., 35 (2012), 16.

25) Q. Zhang and M. Chen: Ironmaking, Suppl. (2005), 117.

26) X. W. Li, J. Chen and W. L. Chen: Wisco Technol., 51 (2013), 1.

27) J. Chen, F. Cao, Y. Y. Guo, H. Chen, J. J. Huang, J. Chen and K. T. Zhen: Proc. 2014 Natl. Iron Production \& Technology and Annual Ironmaking Conf., CSM, Beijing, (2014), 65.

28) T. Wang, W. D. Zhang, L. J. Ren and H. Q. Wei: Ironmaking, 29 (2010), 6 .

29) L. W. Lu, J. J. Chen and W. L. Chen: Ironmaking, 30 (2011), 13.

30) R. L. Zhu: Proc. 2014 Natl. Iron Production \& Technology and Annual Ironmaking Conf., CSM, Beijing, (2014), 31.

31) R. L. Zhu: Ironmaking, 31 (2012), 30.

32) X. L. Wang: Ferrous Metallurgy (Ironmaking Part), Metallurgical Industry Press, Beijing, (2013), 283.

33) W. D. Wang and L. Zhang: Ironmaking, 31 (2012), 9.

34) R. L. Zhu, T. Q. Wang and X. F. Wang: China Metall., 23 (2013), 30.

35) Z. K. Gao and T. Gao: China Metall., 23 (2013), 8.

36) Z. K. Gao, W. D. Wang and T. Gao: Ironmaking, 29 (2010), 13

37) Z. K. Gao, W. G. Song and T. Gao: Proc. 2009 Annual Ironmaking and Steelmaking Conf., CSM, Beijing, (2009), 381. 